ks. Jan Dziedzic ${ }^{1}$

Uniwersytet Papieski Jana Pawła II w Krakowie

\title{
Zjawisko migracji Polaków. Następstwa i duszpasterska rola Kościoła
}

Papież Franciszek, odbierając 6 maja 2016 roku międzynarodową Nagrodę Karola Wielkiego przyznawaną przez niemieckie miasto Aachen (Akwizgran), powiedział: „Marzę o Europie, gdzie bycie imigrantem nie byłoby przestępstwem, ale zaproszeniem do większego zaangażowania na rzecz godności wszystkich istot ludzkich"2. Słowa papieża są wezwaniem do szacunku wobec każdego człowieka. Apel ten jest bardzo aktualny zwłaszcza dzisiaj, gdy do Europy napływa wielu migrantów szukających schronienia przed wojną, konfliktami, codziennym zagrożeniem swojego życia.

Migracje mają miejsce z różnych powodów. Są one spowodowane szukaniem obrony życia, wolności, większego bezpieczeństwa. Wyjazd może być spowodowany poszukiwaniem lepszej pracy, z czym wiąże się

1 Ks. Jan Dziedzic - kierownik Katedry Psychologii Pastoralnej na Wydziale Teologicznym Uniwersytetu Papieskiego Jana Pawła II w Krakowie, prodziekan tego wydziału. Przewodniczący senackiej Komisji ds. Zagranicznych. Koordynator współpracy naukowej z Wydziałem Teologii Katolickiej Uniwersytetu Ruhry w Bochum. Kierownik Uniwersytetu Trzeciego Wieku przy UPJPII. Dyrektor konwiktu księży studentów UPJPII. Członek PosT-Netzwerks der mittelund osteuropäischen Pastoraltheologinnen und Pastoraltheologen z siedzibą w Wiedniu. Skupia się na badaniach naukowych z dziedzin psychologii pastoralnej i tanatologii.

2 Papież Franciszek, Przemówienie z okazji odebrania nagrody Karola Wielkiego, Watykan, 6.05.2016. 
poprawa warunków ekonomicznych całej rodziny. Niezależnie od powodów opuszczenia swojej ojczyzny każda migracja jest wyzwaniem. Z jednej strony jest ona szansą na poprawę jakości życia, z drugiej strony „staje się kalwarią dla przetrwania, w której mężczyźni i kobiety są bardziej ofiarami niż twórcami odpowiedzialnymi za swój migracyjny los"3. Każda migracja związana jest więc z jakimś wysiłkiem zintegrowania $z$ otoczeniem. „Droga integracji obejmuje prawa i obowiązki, uwage i troskę o to, by migranci mieli godne życie, ale wymaga ona także uwagi ze strony migrantów na wartości, jakie oferuje społeczeństwo, w którym się aklimatyzują"4.

Prezentowany artykuł wpisuje się w dzisiejszą dyskusję na temat migracji. Przybliża on problematykę emigracji Polaków, którzy w ostatnich latach bardzo często opuszczali kraj czasowo albo na stałe. Kierunkiem migracji była najczęściej Europa, a tu dominowały takie kraje jak Wielka Brytania, Niemcy czy Irlandia. Najczęściej powodem wyjazdów były kwestie ekonomiczne i brak pracy albo dobrze płatnej pracy.

W celu całościowego przybliżenia zaproponowanego zagadnienia zostanie najpierw omówione zjawisko migracji Polaków, ich konsekwencje - zarówno pozytywne, jak i negatywne - oraz duszpasterska troska o migrantów, która wiąże się z życiem religijnym i rozwojem duchowym polskich katolików przebywających za granicą. Duszpasterstwo polonijne jest bardzo szeroko rozbudowane w Europie i na świecie, co ułatwia rodakom przebywającym poza granicami kraju integralny rozwój duchowy i ludzki.

\section{Zjawisko migracji Polaków}

Okresem największych migracji Polaków nie jest wiek XX ani XXI. Już w latach 1860-1940 Polskę opuściło $5 \mathrm{mln}$ osób, z czego około 1,7 mln wyjechało do Stanów Zjednoczonych. W 1913 roku Polacy stanowili oko-

3 Benedykt XVI, Migracje:pielgrzymka wiary i nadziei, Orędzie na Światowy Dzień Migranta i Uchodźcy 2013, Watykan, 12.10.2012.

4 Benedykt XVI, Migracje: pielgrzymka wiary i nadziei, dok. cyt. 
ło 40 proc. górników w Zagłębiu Ruhry. Przyjmuje się, że w momencie zakończenia II wojny światowej poza granicami Polski znalazło się 20 proc. tych, którzy przeżyli wojnę. Masowe przemieszczania ludności do roku 1950 objęły od 3 do 4 mln osób 5 .

W końcówce XIX wieku Polacy masowo migrowali do Stanów Zjednoczonych, Kanady, a nieco później do Brazylii. Skalę uchodźstwa do USA do 1914 roku szacuje się na 2,2 mln osób. Wysoka stopa migracji zarobkowych utrzymywała się w okresie międzywojennym, kiedy wyjechało ok. 2,2 mln obywateli ${ }^{6}$. Po II wojnie światowej, w latach 60. i 80. XX wieku, wielkość polskiej diaspory w USA wzrosła z $2 \mathrm{mln} 779$ tys. do $8 \mathrm{mln}$ 228 tys. ${ }^{7}$.

Przyjmuje się, że w latach 1971-1980 do krajów Europy Zachodniej wyjechało łącznie ponad 4,2 mln osób, z czego około $3 \mathrm{mln}$ w latach 19761980. Narodowy Spis Powszechny przeprowadzony w roku 1988 wykazał, że poza granicami kraju przez okres powyżej 2 miesięcy przebywało 507,8 tys. osób, czyli 1,3 proc. ogółu ludności ${ }^{8}$. Łączna skala odpływu migracyjnego w latach 1980-1989 szacowana jest na 2,2-2,35 mln osób. W okresie transformacji ustrojowej liczba migrantów ustabilizowała się na poziomie $1,8-2$ proc. populacji ${ }^{9}$.

Na procesy mobilności duży wpływ miała transformacja systemowa po roku 1989. Główny Urząd Statyczny szacuje, że w końcu 2015 roku poza granicami Polski przebywało czasowo ok. 2 mln 397 tys. mieszkańców naszego kraju. Jest to o 77 tys. (3,3 proc.) więcej niż w 2014 roku. W Europie w 2015 roku przebywało około 2 mln 98 tys. Polaków, przy czym zdecydowana większość (ok. 1 mln 983 tys.) w krajach członkowskich UE. Liczba ta zwiększyła się o 82 tys. w stosunku do 2014 roku. Spośród krajów UE nadal najwięcej osób przebywało w Wielkiej Brytanii

5 Por. P. Kaczmarczyk, J. Tyrowicz, Wspótczesne migracje Polaków, „Bezrobocie org.pl” 1 (2007) nr 1, s. 3-4.

6 Por. B. Walczak, Dziecko, rodzina i szkoła wobec migracji rodzicielskich: 10 lat po akcesji do Unii Europejskiej, Warszawa 2014, s. 7.

7 Por. D. Mostwin, Emigranci polscy w USA, Lublin 1991, s. 19.

8 Por. P. Kaczmarczyk, J. Tyrowicz, Współczesne migracje Polaków, dz.cyt., s. 4.

9 Por. P. Kaczmarczyk, E. Kępińska, J. Napierała, Próba oceny „natężenia” migracji w regionach wysyłajacych przez pryzmat gospodarstw domowych, w: Współczesne migracje zagraniczne Polaków. Aspekty lokalne i regionalne, red. W. P. Kaczmarczyk, Warszawa 2008, s. 16-17. 
(720 tys.), Niemczech (655 tys.), Holandii (112 tys.) oraz Irlandii (111 tys.) i we Włoszech (94 tys.) $)^{10}$.

W 2015 roku odnotowano znaczący wzrost liczby Polaków przebywających w Niemczech oraz w Wielkiej Brytanii. W przypadku Niemiec liczba ta wzrosła o 41 tys., czyli prawie o 7 proc. W Wielkiej Brytanii odnotowano wzrost liczby Polaków o 35 tys. (5,1 proc.). Spośród krajów UE niewielki wzrost zaobserwowano również w Belgii, Holandii, Szwecji, Austrii, Danii oraz we Francji ${ }^{11}$. Jednocześnie nastąpił wzrost liczby osób przebywających w krajach europejskich nienależących do UE, w tym Norwegii. W 2015 roku przebywało w tym kraju 84 tys. Polaków ${ }^{12}$. Trzeba zaznaczyć, że powyższe analizy utrudnia fakt podwójnego obywatelstwa części naszych rodaków, co sprawia, że osoba, która ma obywatelstwo polskie oraz kraju przyjmującego, nie jest traktowana w tym kraju jako obywatel polski.

$\mathrm{Z}$ badań przeprowadzonych w losowo wybranych 100 polskich szkołach, które miało miejsce w 2014 roku, wynika, że siedem na dziesięć migracji rodzicielskich to wyjazd samego ojca (opiekuna), 14,8 proc. to migracja matki, 17,2 proc. to migracja obydwojga, w 2/3 przypadki o charakterze naprzemiennym. Najczęściej wybieraną strategią są wyjazdy krótkotrwałe (do dwóch miesięcy). Na rozłąkę przekraczającą jeden rok kalendarzowy zdecydowało się 11,7 proc. spośród migrujących matek i 19,7 proc. ojców. Takiej długotrwałej rozłąki doświadczyło 3,2 proc. ogółu uczniów ${ }^{13}$. A zatem wysoki poziom odpływu migracyjnego nie jest dla Polaków fenomenem nowym.

Według CRONEM motywy emigracji obywateli polskich do Wielkiej Brytanii rysują się w następujący sposób: dla największej grupy

10 Por. Główny Urząd Statystyczny, Informacja o rozmiarach i kierunkach czasowej emigracji z Polski w latach 2004-2015, Warszawa 5 września 2016, s. 2, http://stat.gov.pl/obszary-tematyczne/ludnosc/migracje-zagraniczne-ludnosci/informacja-o-rozmiarach-i-kierunkach-emigracji-z-polski-w-latach-20042015,2,9.html (10.06.2017).

11 Por. Główny Urząd Statystyczny, Informacja o rozmiarach $i$ kierunkach czasowej emigracji z Polski w latach 2004-2015, dz. cyt.

12 Por. Główny Urząd Statystyczny, Informacja o rozmiarach i kierunkach czasowej emigracji z Polski w latach 2004-2015, dz. cyt.

13 Por. B. Walczak, Dziecko, rodzina i szkoła wobec migracji rodzicielskich: 10 lat po aneksji do Unii Europejskiej, Warszawa 2014, s. 91. 
58,4 proc. respondentów powodem opuszczenia Polski są wyższe zarobki i bezrobocie w Polsce. 41,4 proc. jako powód emigracji wymienia szerszy wachlarz możliwości, jakie daje emigracja, oraz łatwiejsze życie. 31,3 proc. zdecydowało się na emigracje ze względu na rozwój osobisty i zawodowy. Dla 17,8 proc. objętych sondażem powodem wyjazdu z Polski była ucieczka od trudnej sytuacji politycznej i ekonomicznej. 13,9 proc. obywateli polskich osiedliło się w Wielkiej Brytanii ze względu na lepszą przyszłość dla dzieci. CRONEM podkreśla, że wspólnym mianownikiem dla wszystkich podanych powodów wyjazdu jest czynnik finansowy, a ogólnie rzecz biorąc egzystencjalny ${ }^{14}$.

Spośród respondentów poniżej 24 roku życia 55 proc. jako przyczynę emigracji podaje czynnik finansowy. W grupie respondentów powyżej 46 roku życia finansowy powód wyjazdów zaznaczyło 83 proc. badanych. Motywy takie jak „łatwiejsze życie” czy „rozwój osobisty i zawodowy” z reguły wymieniali ludzie młodsi i lepiej wykształceni. Dla tej grupy oddzielnym czynnikiem motywacyjnym jest „chęć mieszkania w innym kraju, możliwość poznania języka, chęć zyskania nowych znajomych oraz doświadczenie życia w miastach globalnych, takich jak Londyn"15.

\section{Następstwa migracji z Polski}

Wyjazdy zagraniczne dają szansę na dalszy rozwój, mogą też być zagrożeniem. Badania statystyczne mówią zarówno o sukcesach odniesionych przez migrantów, jak i o ich porażkach. Wiąże się to z dyspozycjami indywidualnymi wyjeżdżających, ich zdolnościami, zasobami osobowościowymi czy przywiązaniem do tradycji, wartości i religii.

\subsection{Pozytywne skutki}

Przemieszczanie się ludności ma wiele pozytywnych skutków. Podróże w celach handlowych, turystycznych, zarobkowych czy naukowych wpisu-

14 Por. M. Hułas, Dylematy emigracji poakcesyjnej, „Cywilizacja” 32 (2010), s. 104.

15 Por. M. Hułas, Dylematy emigracji poakcesyjnej, dz. cyt., s. 104. 
ją się w wielowymiarowy rozwój człowieka. Historia mówi o tym, że wielu Polaków, nie tylko zamożnych, podejmowało studia na uniwersytetach, np. we Włoszech, a później obejmowało wiele ważnych społecznie stanowisk świeckich i kościelnych. Dzięki temu nasz kraj mógł korzystać z dorobku Europy zachodniej w dziedzinie prawa, literatury czy architektury ${ }^{16}$.

Przebywający na emigracji przyczyniali się także do rozsławienia Polski: choćby polski kompozytor i pianista Fryderyk Chopin (1810-1849) czy dwukrotna laureatka nagrody Nobla z dziedziny fizyki i chemii Maria Skłodowska-Curie (1867-1934). Na emigracji powstały wielkie dzieła literatury polskiej, np. Pan Tadeusz. Sam Adam Mickiewicz (1798-1855) pisał w tym dziele o sobie jako emigrancie: „Litwo, Ojczyzno moja! | Ty jesteś jak zdrowie; | Ile cię trzeba cenić, ten tylko się dowie, | Kto cię stracił”.

Przykłady te pokazują, że migracje mają pozytywne skutki. Dotyczy to także dzisiejszych wyjazdów zarobkowych. Mogą one przynieść wiele korzyści, zarówno samemu migrantowi i jego rodzinie, jak i społeczeństwu, z którego pochodzi, czy pracodawcy w kraju emigracji. Wyjazdy zarobkowe dają szansę na znalezienie pracy, której ktoś nie miał, albo pracy lepiej nagradzanej za granicą.

Do pozytywnych konsekwencji migracji zalicza się czynniki ekonomiczne. $\mathrm{Z}$ badań wynika, że pozytywnym następstwem wyjazdów jest możliwość realizacji planów związanych z dużymi nakładami finansowymi, a także zapewnienie rodzinie normalnych warunków do życia. Wyjazdy zarobkowe korzystnie wpływają więc na warunki ekonomiczne rodziny i przyczyniają się do poprawy poziomu życia. Ponadto uzyskane środki materialne finansowo zabezpieczają dzieci i pomagają im w zdobyciu lepszego wykształcenia ${ }^{17}$. Z badań przeprowadzonych przez Marka Okólskiego i Pawła Kaczmarczyka wynika, że co trzeci polski emigrant swoje zarobki z zagranicy wydał na poprawę warunków mieszkaniowych, co czwarty uzyskane środki przeznaczył na lokaty lub spłatę długów. 25 proc. Polaków zainwestowało w edukację dzieci, a 13 proc. we własny rozwój ${ }^{18}$.

16 Por. R. Polak, O emigracji uwagi krytyczne, „Cywilizacja” 32 (2010), s. 120.

17 Por. D. Becker-Pestka, Rodzina w obliczu migracji zarobkowej, "Colloquium WNHiS” 1 (2012), s. 13.

18 Za: B. Więckiewicz, Emigracjazarobkowai jej konsekwencje wżyciu rodzinnym, ,Społeczeństwo i Rodzina" 4 (2008), nr 17, s. 103. 
Przypływ zagranicznej waluty jest również istotną korzyścią dla rodzimego kraju migranta. Pieniądze przesyłane przez emigrantów do Polski przyczyniają się zdaniem ekonomistów do zwiększenia wartości polskiej złotówki, co przekłada się na to, że możemy nabyć więcej różnych dóbr konsumpcyjnych czy spędzić taniej zagraniczny urlop ${ }^{19}$.

Wyjazdy zagraniczne łagodzą niedobór pracy w sytuacji bezrobocia, zwłaszcza gdy jest ono bardzo wysokie. Motywują one do poznawania nowych metod zarządzania i rozwiązywania problemów, co jest bardzo istotnym czynnikiem mobilizującym do rozwoju indywidualnego i zawodowego. Mobilność uczy przedsiębiorczości i inicjatyw właściwych krajom wysoko rozwiniętym ${ }^{20}$. Wyjazdy zagraniczne pomagają w poznaniu nowego języka, kultury i obyczajów. Pozwalają również w realizacji aspiracji zawodowych, zwłaszcza gdy wykonywana praca uczy nowych technik produkcji i pogłębia wiedzę w obrębie nowej „kultury ekonomicznej”, co umożliwia realizację aspiracji zawodowych i aktywizuje ducha inicjatywy ${ }^{21}$.

Zofia Kawczyńska-Butrym uważa, że „długotrwała rozłąka może łagodzić niektóre dysonanse w życiu rodziny, osłabiać nieporozumienia, uświadamiać znaczenie więzi i obecności bliskich osób, przywracać poczucie wartości bycia razem, sprzyjać i pogłębiać więzi" ${ }^{22}$. Rozstanie powoduje, że członkowie rodziny uzmysławiają sobie uczucia, które ich wzajemnie łączą, a także rolę rodziny jako jedności. W rodzinach, których życie było zakłócone z powodu nadużywania alkoholu, stosowania przemocy czy autokratyzmu, wyjazd przywraca poczucie bezpieczeństwa. Ponadto dzieci, uczestnicząc aktywnie w życiu domowym, przygotowują się do wypełniania w przyszłości, w swojej własnej rodzinie, różnych życiowych ról. Obserwując sposoby, w jakie dorośli radzą sobie z problemami, dzieci nabywają także życiowych umiejętności²3.

19 Za: B. Więckiewicz, Emigracja zarobkowa ijej konsekwencje w życiu rodzinnym, dz.cyt., s. 103.

20 Por. J. Gocko, Aspekty etyczne wyjazdów zarobkowych, w: Wyjazdy zarobkowe. Szansa czy zagrożenie? Perspektywa społeczno-moralna, red. K. Glombik, P. Morciniec, Opole 2005, s. 190.

21 Por. M. Kluz, Człowiek w konfrontacji ze współczesną migracją zarobkowa, „Studia Sandomierskie" 20 (2013) nr 2, s. 127.

22 Por. Z. Kawczyńska-Butrym, Migracje. Wybrane zagadnienia, Lublin 2009, s. 74.

23 Por. W. Danielewicz, Społeczne konsekwencje migracji zagranicznych, w: Migracje, uchodźstwo, wielokulturowość, red. D. Lalak, Warszawa 2007, s. 161-162. 
Mobilni robotnicy ułatwiają przezwyciężenie istniejących luk na zagranicznych rynkach pracy. W sytuacji niżu demograficznego i otwartego rynku pracy migranci są poszukiwani, choćby z tego względu, że są tanią siła roboczą. Migranci stają się promotorami nowych partnerskich relacji na płaszczyźnie ekonomicznej, kulturowej, naukowej, społecznej, religijno-moralnej. Ważnym elementem w doświadczeniu życiowym człowieka emigrującego stają się poznanie i szacunek wobec innych narodów, a także szansa urzeczywistniania zasad tolerancji, w tym tolerancji religijnej i wyznaniowej w praktyce życia ${ }^{24}$.

\subsection{Skutki negatywne}

Wyjazdy zagraniczne mają również negatywne skutki. Dotyczą one najpierw samej osoby migrującej. Często na początku wyjeżdżający doświadzcza szoku migracyjnego. Spowodowane jest to zderzeniem z otaczającą innością. Są to inne: kultura, mentalność, język, klimat. Z punktu widzenia struktur państwowych często migrant musi się zetknąć z innym systemem prawnym, inaczej zorganizowanym szkolnictwem i systemem ochrony zdrowia. Obowiązują też odmienne kryteria awansu zawodowego ${ }^{25}$.

Brak zdolności do swobodnego posługiwania się językiem prowadzi do tego, że migranci nie są w stanie podjać pracy i objąć stanowisk odpowiadających kwalifikacjom zdobytym w kraju pochodzenia. Problemy z płynną komunikacją i dobrym zrozumieniem języka obcego mogą przyczyniać się do izolacji w pracy, a także blokować dostęp do informacji na temat przysługujących imigrantom praw. Brak zdolności komunikacyjnych zawsze powoduje niepewność i alienację ${ }^{26}$.

Najczęściej migranci zajmują w kraju, który ich przyjmuje, niższą pozycję w hierarchii społecznej i zawodowej, niż zajmowali w kraju pochodzenia. Wynika to z faktu, że często podejmują pracę poniżej własnych kompetencji, nieodpowiadającą zdobytemu wykształceniu. Poza tym migranci

24 Por. M. Kluz, Człowiek w konfrontacji ze współczesna migracją zarobkowa, dz. cyt., s. 127.

25 Por. M. Hułas, Dylematy emigracji poakcesyjnej, dz. cyt., s. 109.

26 Por. M. Hułas, Dylematy emigracji poakcesyjnej, dz. cyt., s. 109. 
często są opłacani gorzej niż rodzimi pracownicy. Przykładowo Polacy pracujący w Wielkiej Brytanii znajdowali się na dwudziestym szóstym miejscu pod względem wysokości zarobków różnych narodowych grup migracyjnych ${ }^{27}$. Wyznacznikiem niższej pozycji społecznej migranta są warunki mieszkaniowe. Mieszkają oni w mało atrakcyjnych dzielnicach miasta, a warunki lokalowe częściej przypominają noclegownie niż normalne mieszkanie. Bywa tak, że kilka osób wynajmuje dom lub mieszkanie, dzieląc się kosztami $^{28}$.

Migracje wpływają niekorzystnie również na stan zdrowia wyjeżdżających. Częściej zapadają oni na choroby nowotworowe, cukrzycę, bulimię, anoreksję. Dotykają ich także choroby psychiczne. W badaniach australijskich w roku 1986 wykazano, że Polacy ponaddwuipółkrotnie częściej niż reszta australijskiego społeczeństwa byli hospitalizowani w szpitalach psychiatrycznych. Ponad pięciokrotnie częściej rozpoznawano u nich schizofrenię i trzykrotnie częściej alkoholizm²9.

Podkreśla się także ambiwalentność (syndrom) podwójnych więzów. Jest to jakby życie w zawieszeniu pomiędzy krajem pochodzenia a krajem emigracji. Zakłada się, że warunkiem udanej imigracji jest jak najszybsza adaptacja do nowych warunków, dlatego imigranci muszą określić swoją pozycję wobec kraju pochodzenia, jak i „nowej ojczyzny” oraz zinterioryzować swój nowy status ${ }^{30}$.

Badacze podkreślają, że migracje przyczyniają się do rozpadu życia rodzinnego. Przeszkodą w budowaniu i umocnieniu więzi w małżeństwie jest z pewnością nieobecność współmałżonka, rozstanie i związane z tym poczucie osamotnienia. Przez migracje jednego ze współmałżonków zostają osłabione interakcje między członkami rodziny. W efekcie rodzina - z punktu widzenia jej rytmu życiowego - jest zdestabilizowana. Funkcjonuje w sposób pełny w czasie okresowego powrotu migran-

27 Por. Z. Kawczyńska-Butrym, Zdrowotne aspekty migracji, „Etos” 22 (2009) nr 3-4 (8788), s. 265-266.

28 Por. Z. Kawczyńska-Butrym, Zdrowotne aspekty migracji, dz. cyt., s. 265-266.

29 Por. Z. Kawczyńska-Butrym, Zdrowotne aspekty migracji, dz. cyt., s. 268-270.

30 Por. M. Hułas, Dylematy emigracji poakcesyjnej, „Cywilizacja” 32 (2010), s. 109-110. 
ta i w sposób dysfunkcyjny w sytuacji, gdy jego nieobecność powoduje lukę w strukturze rodziny ${ }^{31}$.

Na skutek braku wspólnego zamieszkania małżonek przebywający poza domem nie uczestniczy w pełnym życiu rodziny. Wyjazd jednego z małżonków wpływa na osłabienie więzi w małżeństwie. Konsekwencją rozłąki może być nawet rozpad małżeństwa lub ponowny wyjazd za granicę ${ }^{32}$.

Dzieci i młodzież z rodzin migracyjnych znajdują się w obszarze ryzyka wychowawczego. Rozstanie z rodzicem przyczynia się do niestabilnych postaw dzieci. Pojawiają się stany ambiwalentnych emocji, z jednej strony radości związanej z przyjazdem rodziców, a z drugiej strony smutku, a nawet rozpaczy przy ich wyjeździe. Doświadczanie niepokoju, lęku, obaw i wątpliwości powoduje niekiedy zaburzenia w zachowaniu ${ }^{33}$. Rozłąka z rodzicami może spowodować u dzieci problemy z samooceną, trudności w budowaniu relacji z kolegami, brak zaufania. W szkolnej edukacji u dzieci migrujących rodziców pojawiają się także kłopoty związane z nauką, trudności wychowawcze, nieobecność na lekcjach, sięganie po alkohol, ucieczki i inne negatywne zjawiska ${ }^{34}$.

Migracje zarobkowe mogą negatywnie oddziaływać na motywację do inwestowania w rozwój osobisty i zawodowy. Dowodem na to są choćby badania przeprowadzone na Opolszczyźnie. Wśród autochtonów w wieku 18-25 lat naukę kontynuowało tylko 35 proc. osób. W przypadku ludności bez prawa do niemieckiego obywatelstwa było to 57 proc. Wskazuje to na fakt, że migracje zarobkowe mogą negatywnie oddziaływać na motywację

31 Por. D. Becker-Pestka, Rodzina w obliczu migracji zarobkowej, dz.cyt., s. 14-15; D. Niedźwiedzka, Migracje i tożsamość. Od teorii do analizy przypadku, Kraków 2010, s. 113.

32 Por. D. Becker-Pestka, Rodzina w obliczu migracji zarobkowej, dz.cyt., s. 15; M. Jawna, Emigracja zarobkowa a problem eurosieroctwa, „Ogrody Nauk i Sztuk” 3 (2013), s. 92; M. Wyżlic, Migracja zarobkowa - zagrożeniem dla więzi małżeńskiej, „Cywilizacja” 32 (2010), s. 128-137; M. Wyżlic, Communio małżeńskie w perspektywie migracji, „Roczniki Teologiczne” 54 (2007) z. 10, s. 153-168.

33 Por. G. Miłkowska, Wychowawcze i społeczne skutki emigracji zarobkowej dla rozwoju dzieci na przykładzie regionu częstochowskiego, w: Smak emigracji. Dramaty dzieci, red. M. Janukowycz, Kraków 2009, s. 104, za: D. Becker-Pestka, Rodzina w obliczu migracji zarobkowej, dz. cyt., s. 17.

${ }^{34}$ Por. S. Kozak, Patologia eurosieroctwa $w$ Polsce. Skutki migracji zarobkowej dla dzieci i ich rodzin, Warszawa 2010, s. 113, za: D. Becker-Pestka, Rodzina w obliczu migracji zarobkowej, dz. cyt., s. 17. 
do dalszego kształcenia się wśród ludzi młodych, zwłaszcza gdy sektory migracyjne obejmują prace, gdzie nie są wymagane żadne kompetencje czy kwalifikacje ${ }^{35}$. Migracje są również postrzegane w kategoriach porażki indywidualnej. $O$ ile wyjazdy zagraniczne są powodowane marzeniem o sukcesie finansowym, o tyle jednak są one również informacją mówiącą o niemożności poradzenia sobie z rzeczywistością w kraju ${ }^{36}$.

\section{Wsparcie duszpasterskie polskich migrantów}

Przy wspieraniu duszpasterskim Polonii pomaga odniesienie się do nauczania Kościoła. Odwołanie się zarówno do Pisma Świętego, jak i dokumentów papieskich ułatwia szersze i głębsze spojrzenie na migracje w kontekście historii zbawienia. Każdy chrześcijanin jest w drodze i dąży do życia wiecznego, które jest jego celem, niezależnie od tego, gdzie przebywa i mieszka. Wszyscy też mamy taką samą godność, bo zostaliśmy stworzeni na obraz i podobieństwo Boże.

\subsection{Kościół wobec migrantów}

Problematyka migracji zawsze była bardzo bliska Kościołowi ${ }^{37}$. Już bowiem u zarania dziejów lud Boży był wezwany do zmiany miejsca zamieszkania. I tak Abraham słyszy od Boga: „Wyjdź ze swego kraju, spośród grona krewnych, z domu ojca, do kraju, który ci wskażę" (Rdz 12, 1). Emigracja Abrahama staje się znakiem wyróżniającym lud Boży, który jest wezwany do opuszczenia dotychczasowej ojczyzny i wyruszenia w kierunku nowego nieba i nowej ziemi ${ }^{38}$. Przykład „ludu w drodze” ukazuje

35 Por. P. Kaczmarczyk, J. Tyrowicz, Współczesne migracje Polaków, s. 13; por. także: M. Mój, Migracje zarobkowei ich konsekwencje dla rodzinna przykładzie województwa opolskiego, „Pogranicze. Polish Borderlands Studies" 3 (2015) nr 2, s. 175-190.

${ }^{36}$ Por. P. Kaczmarczyk, J. Tyrowicz, Współczesne migracje Polaków, dz. cyt., s. 13.

37 Por. T. Pieronek, Stolica Apostolska wobec migracji i migrantów, w: Migracje. Religie i Kościoły wobec migracji i migrantów, red. J. E. Zamojski, Warszawa 2009, s. 19-37.

38 Por. J. Gocko, Aspekty etyczne wyjazdów zarobkowych, w: Wyjazdy zarobkowe. Szansa czy zagrożenie? Perspektywa społeczno-moralna, red. K. Glombik, P. Morciniec, Opole 2005, s. 185. 
Księga Wyjścia. W historii zbawienia migranci mają bardzo wysoki status. Z nimi jest związany nakaz Boży: „Nie będziesz gnębił i nie będziesz uciskał cudzoziemców, bo wy sami byliście cudzoziemcami w ziemi egipskiej” (Wj 22, 20); „Wy także miłujcie cudzoziemca, boście sami byli cudzoziemcami w ziemi egipskiej" (Pwt 10, 19) ${ }^{39}$.

Instrukcja Papieskiej Rady do Spraw Migrantów i Podróżujących Erga migrantes caritas Christi z 2004 roku podkreśla, że Kościół zawsze odkrywał w migrantach oblicze Chrystusa, który był obcym i przychodniem (por. Mt 25, 35), w Maryi zaś dostrzegał ikonę kobiety wędrującej (por. nr 12, 14). Kto przyjął obcokrajowca, rozpoznał głos Jezusa Chrystusa: „Oto stoję u drzwi i kołaczę" (Ap 3, 20) ${ }^{40}$.

Szacunek wobec migrantów opisywany w Biblii przekłada się na nauczanie Kościoła. Jego podstawą jest respekt wobec godności każdego człowieka. W Caritatis in veritate czytamy: „emigrant jest osobą ludzką, która - jako taka - ma niezbywalne i podstawowe prawa, które powinni szanować wszyscy w każdej sytuacji” (Caritas in veritate, 62). Dlatego „nikogo nie wolno uważać za niepotrzebnego, będącego nie na swoim miejscu czy do odrzucenia" ${ }^{41}$. Już papież Paweł VI stwierdził, że „rozluźnienie braterskich więzi zarówno między ludźmi, jak i między narodami” jest głęboką przyczyną zacofania (Populorum progressio, 66)" ${ }^{42}$.W ten kontekst dobitnie wpisują się słowa Soboru Watykańskiego II: „Wszystkie [...] ludy stanowią jedną wspólnotę, mają jeden początek, ponieważ Bóg sprawił, że rodzaj ludzki zamieszkuje całą powierzchnię ziemi (por. Dz 17, 26), mają też jeden ostateczny cel - Boga. Jego opatrzność, świadectwo dobroci i zbawcze plany rozciągają się na wszystkich ludzi” (Nostra aetate, 1).

Słowa te są tym bardziej aktualne, że w społeczeństwie globalizującym się dobro wspólne i zaangażowanie na jego rzecz nie mogą nie odnosić się

39 Franciszek, Imigranci niepetnoletni, bezbronni i pozbawieni głosu. Orędzie na Światowy Dzień Migranta i Uchodźcy, 15 stycznia 2017.

40 Por. Franciszek, Orędzie na Światowy Dzień Migranta i Uchodźcy 2016, Watykan, 12.09.2015.

41 Franciszek, Orędzie na Światowy Dzień Migranta i Uchodźcy 2015, Watykan, 3.09.2014.

42 Benedykt XVI, Św. Paweł migrant i Apostoł Narodów, Orędzie na 97 Światowy Dzień Migranta i Uchodźcy 2011, Castel Gandolfo, 27 września 2010. 
do wszystkich ludzi (Caritas in veritate, 7) ${ }^{43}$. Zdaniem papieża Franciszka na „globalizację migracji” powinno się zareagować „globalizacją miłości i współczucia”. Żaden człowiek nie może być uznany za niepotrzebnego, będącego nie na swoim miejscu. Uchodźca, imigrant czy azylant nie może być traktowany jak „,pionek na szachownicy ludzkości” albo jak „człowiek skazany na przemiał" ${ }^{44}$.

\subsection{Podstawy duszpasterskiej troski o polskich migrantów}

Kościół naucza, że każdy człowiek ma prawo do migracji w podwójnym aspekcie: mianowicie ma możność opuścić własny kraj oraz udać się do innego w poszukiwaniu lepszych warunków życia ${ }^{45}$. „Prawo człowieka do migrowania - jak przypomina konstytucja soborowa Gaudium et spes w nr. 65 - należy do podstawowych praw ludzkich, wraz z przysługującym każdemu wyborem osiedlenia się tam, gdzie jak sądzi, będzie mógł lepiej wykorzystywać w życiu swoje zdolności i realizować aspiracje i projekty ${ }^{46}$. Kościół nikogo nie wyklucza z zakresu swojego posługiwania ${ }^{47}$. Jest więc również solidarny ze światem migrantów. Papież Franciszek zapewnia, że nikt nie jest obcy we wspólnocie chrześcijańskiej, „obejmującej osoby każdego narodu i wszystkich pokoleń, ludów i języków" (Ap 7, 9) ${ }^{48}$.

Parafie udzielające pomocy migrantom realizują podstawową misję Kościoła. Papież Benedykt XVI mówi: „przyjmowanie uchodźców i udzielanie im gościny jest obowiązkiem wszystkich, wynikającym z ludzkiej

43 Benedykt XVI, Św. Paweł migrant i Apostoł Narodów, dok. cyt.

44 Por. Franciszek, Migranci i uchodźcy: ku lepszemu światu, Orędzie na Światowy Dzień Migranta i Uchodźcy 2014, Watykan 5.08.2013, https://w2.vatican.va/content/france$\mathrm{sco} / \mathrm{pl} /$ messages/migration/documents/papa-francesco_20130805_world-migrants-day. html (30.07.2017), także: Polityczno-prawne i społeczne aspekty współczesnych migracji, pod red. I. Oleksiewicz, W. Fehlera, Warszawa 2016, s. 25.

45 Orędzie na Światowy Dzień Migranta 2001, 3; por. Jan XXIII, enc. Mater et Magistra, 30; Paweł VI, list apost. Octogesima adveniens, 17.

46 Benedykt XVI, Migracje: pielgrzymka wiary i nadziei, Orędzie na Światowy Dzień Migranta i Uchodźcy 2013, Watykan, 12.10.2012.

47 Por. J. Balicki, Imigranci i uchodźcy w Unii Europejskie. Humanizacja polityki imigracyjnej i azylowej, Warszawa 2012, s. 257-259.

48 Franciszek, Imigranci niepełnoletni, bezbronni i pozbawieni głosu, dok. cyt. 
solidarności, która nakazuje nam zadbać o to, by nie poczuli się odizolowani z powodu nietolerancji i obojętności" ${ }^{49}$.

Zdaniem papieża Franciszka powołaniem Kościoła jest pokonywanie granic i umożliwianie „przejścia od postawy obronnej, nacechowanej strachem, brakiem zainteresowania i tendencją do marginalizacji [...] do postawy opartej na kulturze s potkania, jedynej, która potrafi budować świat bardziej sprawiedliwy i braterski"50. Papież ubolewa, że we współczesnej cywilizacji istnieje nadal niebezpieczeństwo wykluczenia najsłabszych, tzw. kultur a o dr zu ca n ia. „Nie ma miejsca ani dla starca, ani dla niechcianego dziecka. Nie ma czasu, aby zatrzymać się z ubogim na skraju drogi. Czasami wydaje się, że dla niektórych relacje międzyludzkie są regulowane przez dwa nowoczesne «dogmaty»: skuteczność i pragmatyzm" ${ }^{51}$. Do kultury odrzucenia należy również zaliczyć chęć nadmiernego zysku i konsumpcjonizm. „Kiedy psuje się komputer, robi się tragedię, ale ubóstwo, potrzeby, dramaty tak wielu osób stają się czymś normalnym. Jeśli w zimową noc tutaj w pobliżu, na przykład przy ul. Ottaviano, umiera człowiek, nie budzi to zainteresowania. Jeśli w tylu częściach świata są dzieci, które nie mają co jeść, nie budzi to zainteresowania, wydaje się, że to rzecz normalna. Tak nie może być! A jednak takie rzeczy stają się czymś normalnym: to, że ludzie bezdomni umierają z zimna na ulicy, nie budzi zainteresowania. Natomiast spadek notowań o 10 punktów na giełdach w kilku miastach jest tragedią. Człowiek, który umiera, nie budzi zainteresowania, ale jeśli notowania giełdowe wykazują spadek o 10 punktów, to jest tragedia! W ten sposób osoby są odrzucane, jakby były odpadami” ${ }^{52}$.

49 Benedykt XVI, Św. Paweł migrant i Apostoł Narodów, Orędzie na 97 Światowy Dzień Migranta i Uchodźcy 2011r., dok. cyt.

50 Franciszek, Orędzie na Światowy Dzień Migranta i Uchodźcy 2015, dok. cyt.

51 Franciszek, Papież do duchownych: Nie kierujcie sięjedynie skutecznościa, Rio de Janeiro, 27.07.2013, http://www.deon.pl/religia/serwis-papieski/dokumenty/homilie-papiez-franciszek/art,20,papiez-do-duchownych-nie-kierujcie-sie-jedynie-skutecznoscia.html (20.07.2017).

52 Franciszek, Przemówienie na audiencji ogólnej, 5 czerwca 2013, http://w2.vatican. va/content/francesco/pl/audiences/2013/documents/papa-francesco_20130605_udienza-generale.html (27.11.2017). 
Ponieważ migranci mogą zostać skazani na różne formy marginalizacji, w parafiach istotne jest budowanie „kultury spotkania”. Chodzi o to, aby stworzyć migrantom bardziej humanitarne warunki ${ }^{53}$. Trzeba pamiętać, że migranci oczekują pomocy innych. W encyklice Caritas in veritate czytamy: „W rzeczywistości ci, którzy migrują, ufają, że zostaną przyjęci, otrzymają solidarną pomoc i spotkają osoby, które rozumiejąc trudności i tragedię swoich bliźnich, a także dostrzegając różne ich wartości i zasoby, będą gotowe okazywać sobie ludzką życzliwość i dzielić się dobrami materialnymi z potrzebującymi i poszkodowanymi (Caritas in veritate, 43). Nie można zapominać, że migranci i uchodźcy, poprzez wykorzystywanie swoich umiejętności zawodowych, swojego dziedzictwa społeczno-kulturowego mogą wiele wnieść w dobrobyt kraju, do którego przybyli ${ }^{54}$.

Patrząc w przyszłość - w opinii papieża Franciszka - ważne jest to, aby stworzyć warunki pozwalające na stopniowe eliminowanie przyczyn migracji. Wydaje się konieczne, aby na poziomie światowym szerzyć porządek gospodarczo-finansowy bardziej sprawiedliwy i zrównoważony. Potrzebne jest również wzmożenie wysiłków na rzecz pokoju, który jest nieodzownym warunkiem wszelkiego autentycznego postępu ${ }^{55}$.

\subsection{Duszpasterstwo polonijne}

Polacy na całym świecie są objęci opieką duszpasterską. Liczba duchownych i jednostek organizujących, takich jak Polskie Misje Katolickie, jest dowodem na ogromne potrzeby religijne, jakie wykazują wierzący Polacy przebywający zagranicą. Oprócz liturgii sprawowanej w języku polskim istotna jest formacja migrantów. Według Jana Pawła II należy w niej zwrócić uwagę na zachowanie własnej tożsamości, integrację w nowym środowisku oraz budowanie hierarchii wartości w oparciu o paradygmat „,bardziej być” niż „mieć”.

53 Franciszek, Orędzie na Światowy Dzień Migranta i Uchodźcy 2015, dok. cyt.

54 Benedykt XVI, Migracje: pielgrzymka wiary i nadziei, Orędzie na Światowy Dzień Migranta i Uchodźcy 2013, dok. cyt.

55 Franciszek, Orędzie na Światowy Dzień Migranta i Uchodźcy 2015, dok. cyt. 


\subsubsection{Potrzeba duszpasterstwa}

Kościół w Polsce, prowadząc swoją duszpasterską misję, jest także wśród Polonii rozsianej po całym świecie ${ }^{56}$. Jak pokazują dane statystyczne, obecnie duszpasterstwo polskojęzyczne regularnie prowadzi ponad 2 tys. duchownych. Do tego należy dodać jeszcze siostry zakonne i księży sporadycznie posługujących Polakom ${ }^{57}$. Przykładowo tylko w samych Niemczech Polska Misja Katolicka składa się z 65 misji skupionych w pięciu dekanatach. W duszpasterstwie polonijnym posługuje 116 księży i 11 sióstr zakonnych. Msze święte w języku polskim odprawiane są regularnie w ok. 313 kościołach lub kaplicach na terenie Niemiec ${ }^{58}$.

Znaczenie duszpasterstwa wśród polskich migrantów doceniał Jan Paweł II ${ }^{59}$. Przemawiając do Polonii w Wielkiej Brytanii w 1982 roku, mówił: „Był z wami od pierwszej chwili obecny Kościół ze swoimi strukturami, był biskup, niezapomniany arcybiskup Józef Gawlina, a później rektor misji, byli duszpasterze i rozwijające się organizacje religijne. Były to jedne z pierwszych ośrodków zorganizowanych. Dzięki zrozumieniu i życzliwości miejscowej hierarchii, ale przede wszystkim dzięki waszej ofiarności i pełnej poświęcenia pracy duszpasterzy powstało tyle polskich kościołów i kaplic, które służą właśnie pogłębieniu więzi z Chrystusem i wprowadzają was w tajemnice Boże, jednocząc z Chrystusem. Przy ośrodkach duszpasterskich powstały również i szkoły uczące języka polskiego"60.

56 Por. N. Jerzak, Rola i zadania Kościoła wobec emigrantów. Odpowiedzialność za obchodzenie sięz emigrantami w Kościele, „Perspectiva. Legnickie Studia Teologiczno-Historyczne” 12 (2013) nr 2 (23), s. 65-67.

57 Por. W. Lachowicz, Jezus Chrystus największym emigrantem i pielgrzymem, „Wspólnota Polska" 3 (2015), s. 44.

58 Por. Polska Misja Katolicka w Niemczech, https://www.pmk-niemcy.eu/polskiemisje.html (20.07.2017).

59 Por. A. Zwoliński, Troska o naród na emigracji, „Cywilizacja” 32 (2010), s. 24-27.

60 Jan Paweł II, Jesteście żywa częścią Polski, Spotkanie z polonia w Wielkiej Brytanii 30 maja 1982, nr 5. https://marszpolonia.com/2012/09/01/jan-pawel-ii-jestescie-zywa-czescia-polski (10.07.2017). 
Konieczność duszpasterskiego wsparcia migrantów dostrzegają również polscy biskupi. W liście z 2006 roku o emigracji Konferencja Episkopatu Polski pisze: „Opuszczenie ojczystego kraju, niezależnie od jego przyczyn, jest zawsze swego rodzaju dramatem, który emigrant uświadamia sobie dopiero wówczas, gdy staje wobec trudnego problemu dostosowania się do życia w nowych, bardzo często niełatwych warunkach. W tej sytuacji szczególnego znaczenia nabiera korzystanie z opieki religijnej w ojczystym języku. Dlatego emigrantom z Polski w każdym okresie towarzyszyli kapłani diecezjalni i zakonni oraz siostry zakonne. Parafie i inne placówki duszpasterskie stawały się dla wychodźców bezcennym, moralnym oparciem. Powstawały przy nich różnego rodzaju stowarzyszenia i organizacje oraz szkoły polskie. W wielu krajach polskie parafie i misje duszpasterskie są wciąż jedynymi ośrodkami polskiej tożsamości i kultury. Ich zasługi na tym polu są ogromne"61.

Duszpasterze pracujący wśród Polonii zabiegają o to, aby migranci mieli swoją liturgię i nabożeństwa w języku polskim. Troszczą się o zapewnienie opieki duszpasterskiej poprzez odwiedziny rodzin, osób starszych i chorych. Opieka duszpasterska pomaga migrantom w pogłębieniu wiary i chroni ich od zagrożeń, jakie niosą ze sobą sekty i nowe ruchy religijne, które niekiedy usiłują nakłonić migranta do porzucenia wiary. Kościół, który jest powołany do niesienia pomocy migrantom, ma za zadanie wspierać ich duchowo i pomóc przybyszom pokonać zagrożenia związane z emigracją ${ }^{62}$.

\subsubsection{Wskazania dla polskich migrantów}

W formacji migrantów bardzo duże znaczenie odgrywa nauczanie Jana Pawła II. W jego licznych przemówieniach do Polonii można odnaleźć

${ }_{61}$ List Episkopatu Polski o duszpasterstwie emigracji, Warszawa 18-19.10.2006 http:// www.opoka.org.pl/biblioteka/W/WE/kep/duszp_emigracji_18102006.html (20.07.2017).

${ }_{62}$ Por. J. Orzeszyna, Pozytywny i negatywny aspekt migracji zarobkowej, „Analecta Cracoviensia" 41 (2009), s. 278; A. Orczykowski, Kościół wobec polskiej emigracji dawnej i wspótczesnej, „Cywilizacja” 32 (2010), s. 195-204; J. Młyński, W. Szewczyk, Migracje zarobkowe Polaków. Badania i refleksje, Tarnów 2010, s. 106-111. 
podstawowe założenia, nieodzowne do kształtowania postaw przebywających poza ojczyzną Polaków. Zasadniczo chodzi o pogłębienie własnej tożsamości ${ }^{63}$, integrację i miłość do nowej ojczyzny, budowanie właściwej hierarchii wartości oraz wychowanie ku dojrzałości.

W budowaniu własnej tożsamości - zdaniem Jana Pawła II - istotna jest pamięć o tym, kim jesteśmy i gdzie są nasze korzenie ${ }^{64}$. Naród bowiem żyje „nie tylko w swoim historycznym pniu, nad Wisłą, ale także w różnych miejscach świata"65. Niezależnie więc od tego, gdzie są nasze domy i miejsca pracy, zawsze winniśmy się czuć jedną wspólnotą ${ }^{66}$. Wzmacniając swoją tożsamość, nie możemy jednak zapomnieć, że należymy do wielkiej wspólnoty narodów i korzystamy z ich dorobku i osiągnięć.

Polacy na emigracji wtedy wypełnią swoje posłannictwo, gdy ich poziom etyczny będzie wysoki, a wiara będzie ośrodkiem życia i działania ${ }^{67}$. Potrzebne jest również wychowanie w duchu chrześcijańskim młodego pokolenia. Papież Jan Paweł II uważa, że jedynie rodzina Bogiem silna, rodzina świadoma swych chrześcijańskich zadań może podołać realizowaniu zadań wychowania pełnego człowieka. Dlatego wzywa on słowami adhortacji Familiaris consortio: „Rodzino, stań się tym, czym jesteś! Zgromadzona razem przez Słowo i Sakrament jako Kościół domowy, stań się tak jak wielki Kościół nauczycielem i matką" (Familiaris consortio, 17, 38).

63 Por. H. Skorowski, Niebezpieczeństwo marginalizacji emigrantówi uchodźców w kontekście integracji europejskiej, „Cywilizacja” 32 (2010), s. 36-37; J. Krotofil, Rola religii w procesie przystosowania polskich migrantów do życia w Wielkiej Brytanii, w: Drogi i rozdroża. Migracje Polaków w Unii Europejskiej po 1 maja 2004 roku. Analiza psychologiczno-socjologiczna, red. H. Grzymała-Moszczyńska, A. Kwiatkowska, J. Roszak, Kraków 2010, s. 265-268.

64 Jan Paweł II, Być i czuć się Polakiem, Przemówienie do Polonii z całego świata, Rzym 1990, „Wspólnota Polska” 3 (2015), s. 3.

65 Jan Paweł II, Przemówienie do Polonii hiszpańskiej, Madryt, 2.11.1982, za: „Wspólnota Polska" 3 (2015), s. 13.

${ }^{66}$ Jan Paweł II, Być i czuć się Polakiem, Przemówienie do Polonii z całego świata, dz. cyt., S. 3.

${ }^{67}$ Jan Paweł II, Jesteście żywa częścią Polski, Spotkanie z Polonią w Wielkiej Brytanii, 30.05.1982, nr 5. https://marszpolonia.com/2012/09/01/jan-pawel-ii-jestescie-zywa-czescia-polski (10.07.2017). 


\section{Zakończenie}

Migracje Polaków nie są fenomenem nowym, miały one miejsce już wcześniej. Pod koniec XIX wieku Polacy wyjeżdżali do Stanów Zjednoczonych, Kanady i Brazylii. Wysoka stopa migracji zarobkowych utrzymywała się w okresie międzywojennym. Po II wojnie światowej liczba migrantów wzrosła do ponad $8 \mathrm{mln}$. W latach 1971-1980 do krajów Europy Zachodniej wyjechało łącznie ponad 4 mln osób. W latach 19801989 skala mobilności szacowana była na 2,2-2,35 miliona osób. W okresie transformacji liczba migrantów ustabilizowała się na poziomie 1,82 proc. populacji. Poza granicami Polski w końcu 2015 roku przebywało czasowo prawie 2,5 mln mieszkańców naszego kraju.

Z wyjazdami zagranicznymi wiążą się zarówno skutki pozytywne, jak i negatywne. Wśród konsekwencji pozytywnych, oprócz aspektów ekonomicznych, wymienia się wszechstronny rozwój człowieka. Migracje pomagająw poznaniu nowych języka, kultury i obyczajów. Mobilność uczy przedsiębiorczości, przybliża nowe techniki produkcji i pogłębia wiedzę w obszarze nowej „kultury ekonomicznej”. Migranci stają się promotorami nowych partnerskich relacji na płaszczyźnie ekonomicznej, kulturowej, naukowej, społecznej, czy religijno-moralnej.

Wśród skutków negatywnych podaje się różnego rodzaju zagrożenia dla osoby migrującej, dla małżeństwa i rodziny, dla życia religijno-moralnego migranta. Migranci na obczyźnie zajmująniższą pozycję w hierarchii społecznej i zawodowej niż we własnej ojczyźnie, podejmują pracę często poniżej kompetencji i są słabiej opłacani niż rodzimi pracownicy, zajmują też niższą pozycję społeczną, ponieważ są traktowani jak obcy. Wyjazd jednego z małżonków wpływa na osłabienie więzi w małżeństwie i przyczynia się nawet do rozwodu. Brak jednego z rodziców ma również negatywny wpływ na wychowanie dzieci. W życiu religijnym może pojawić się osłabienie praktyk religijnych, a nawet zanik wiary.

O emigrantach nie zapomina Kościół. Zwłaszcza wśród ludzi religijnych jego wsparcie odgrywa bardzo istotną rolę. Duszpasterze w swojej misji wobec Polonii odwołują się do nauczania Kościoła. Podkreślają, że emigrant jest osobą ludzką i z tego tytułu ma niezbywalne i podstawowe prawa, które powinni szanować wszyscy ludzie. We wspólnocie chrześci- 
jańskiej żaden migrant nie jest obcy, dlatego, mówiąc językiem papieża Franciszka, należy budować „kulturę spotkania” i w ten sposób sprzeciwiać się „kulturze odrzucenia”.

Podkreślając działalność Kościoła wśród polskich migrantów, Jan Paweł II, spotykając się z Polonią na całym świecie, niejako opracował program rozwoju duchowego i ludzkiego dla osób przebywających za granicą. Podkreślał on, że każdy emigrant powinien pamiętać o: zachowaniu własnej tożsamości, integracji w nowym środowisku, a także o budowaniu zasad moralnych, gdzie „bardziej być” jest ważniejsze niż „mieć”. 


\section{Summary}

\section{Zjawisko migracji Polaków. Następstwa i duszpasterska rola Kościoła}

Migracje Polaków nie są zjawiskiem nowym. Już w XIX wieku Polacy podróżowali do USA i Kanady. W 1913 roku aż 40 proc. górników w Zagłębiu Ruhry stanowili Polacy. Migracje nie ustały po II wojnie światowej. Ich liczba wzrosła do $8 \mathrm{mln}$. Podobnie w latach od 1971 do 1989 Polacy szukali możliwości swojego rozwoju zagranicą. Migracje nie skończyły się także po roku 1989 i trwają do dziś. Statystyki wskazują, że obecnie najwięcej obywateli Polski wyjeżdża do Wielkiej Brytanii, Niemiec, Holandii oraz Irlandii.

Wyjazdy zagraniczne mają skutki zarówno pozytywne, jak i negatywne. Do tych pierwszych zaliczamy poznanie języka obcego, nowej kultury i obyczajów, zapoznanie się z nowymi technikami produkcji, oprawę jakości i standardu ekonomicznego życia. Wśród skutków negatywnych podaje się: osłabienie więzi małżeńskich, a nawet rozpad małżeństwa, eurosieroctwo, osłabienie życia religijnego, większe prawdopodobieństwo chorób, pracę poniżej własnych kompetencji i aspiracji.

O polskich emigrantach nie zapomina Kościół. Polskie Misje Katolickie działają na całym świecie. Mają one pomagać w rozwoju religijnym migranta, zapewniając mu opiekę duszpasterską. Obecnie duszpasterstwo polskojęzyczne regularnie prowadzi ponad 2 tys. duchownych. Podkreślają oni za Janem Pawłem II, który poprzez swoje spotkania z Polonią nakreślił program formacyjny dla emigrantów, że do istotnych elementów pracy nad sobą należą: zachowanie własnej tożsamości, integracja w nowym środowisku oraz budowanie zasad moralnych opartych na paradygmacie „bardziej być” niż „mieć”.

Słowa kluczowe: migracje Polaków, skutki migracji, godność człowieka, duszpasterstwo polonijne

Migrations of Poles over the Years. Their Positive and Negative Effects, and the Pastoral Role of the Church

Migrations of Poles are by no means a new phenomenon. As long ago as the $19^{\text {th }}$ century, Poles travelled abroad, mostly to the USA and Canada. In 1913, for example, Poles constituted as much as $40 \%$ of all miners in the Ruhr area in Germany. The migrations of Poles did not stop after World War 2. On the contrary, the numbers of Polish immigrants suddenly increased, reaching 8 million. Similarly, between 1971 and 1989, Poles continued to look for new opportunities for their professional development in other countries. Migrations of Poles did not stop after 1989 either, and still continue today. Statistics show that the majority of Poles who move abroad today choose Great Britain, Germany, Holland and Ireland. 
Living and working abroad have both positive and negative effects. Learning a foreign language and culture, getting acquainted with the latest technologies as well as improving quality of life are just a few examples of the former. On the other hand, weakening of bonds within the marriage or even marriage breakdown, euro-orphanhood, deterioration of religious/spiritual life, greater risks of falling ill, working below their aspirations and competences are the most common negative effects that Polish immigrants often face.

The Church does not forget their Polish immigrants. There are hundreds of Polish Catholic Missions all over the world whose main aim is to help the immigrants' spiritual development by providing pastoral care and support. There are over two thousand priests working abroad today. They are following the formation programme which John Paul 2nd clearly outlined after his numerous meetings with the Poles living abroad. Its most important elements are: preserving their own identity, their integration in the new, often alien, environment as well as creating strong moral principles, which are based on the paradigm "better to be than to have".

Keywords: migrations of Poles, migration effects, human dignity, Polish Ministry Abroad

\section{Bibliografia}

Balicki J., Imigranci i uchodźcy w Unii Europejskie. Humanizacja polityki imigracyjnej i azylowej, Warszawa 2012.

Becker-Pestka D., Rodzina w obliczu migracji zarobkowej, "Colloquium WNHiS” 1 (2012), s. 9-25.

Benedykt XVI, Migracje: pielgrzymka wiary i nadziei, Orędzie na Światowy Dzień Migranta i Uchodźcy 2013, Watykan, 12.10.2012, https://w2.vatican.va/content/ benedict-xvi/pl/messages/migration/documents/hf_ben-xvi_mes_20121012_world-migrants-day.html (20.07.2017).

Benedykt XVI, Św. Paweł migrant i Apostoł Narodów, Orędzie na 97 Światowy Dzień Migranta i Uchodźcy 2011, Castel Gandolfo, 27.09.2010, https://w2.vatican.va/content/benedict-xvi/pl/messages/migration/documents/hf_ben-xvi_mes_20100927_ world-migrants-day.html (20.07.2017).

Danielewicz W., Społeczne konsekwencje migracji zagranicznych, w: Migracje, uchodźstwo, wielokulturowość, red. D. Lalak, Warszawa 2007, s. 152-166.

Polityczno-prawne i społeczne aspekty współczesnych migracji, pod red. I. Oleksiewicz, W. Fehlera, Warszawa 2016.

Franciszek, Orędzie na Światowy Dzień Migranta i Uchodźcy 2015, Watykan, 3 września 2014, http://w2.vatican.va/content/francesco/pl/messages/migration/ documents/papa-francesco_20140903_world-migrants-day-2015.html (27.11.2017).

Franciszek, Imigranci niepełnoletni, bezbronni i pozbawieni głosu, Orędzie na Światowy Dzień Migranta i Uchodźcy, 15.01.2017, http://episkopat.pl/oredzie-na-swiatowy-dzien-migranta-i-uchodzcy-imigranci-niepelnoletni-bezbronni-i-pozbawieni-glosu (20.07.2017). 
Franciszek, Migranci i uchodźcy: ku lepszemu światu, Orędzie na Światowy Dzień Migranta i Uchodźcy 2014, Watykan 5.08.2013, https://w2.vatican.va/content/france$\mathrm{sco} / \mathrm{pl} / \mathrm{messages} /$ migration/documents/papa-francesco_20130805_world-migrants-day.html (30.07.2017).

Franciszek, Orędzie na Światowy Dzień Migranta i Uchodźcy 2016, Watykan, 12.09.2015, http://w2.vatican.va/content/francesco/pl/messages/migration/documents/papa-francesco_20150912_world-migrants-day-2016.html (27.11.2017).

Franciszek, Papież do duchownych: Nie kierujcie się jedynie skutecznościa, Rio de Janeiro, 27 lipca 2013 http://www.deon.pl/religia/serwis-papieski/dokumenty/ homilie-papiez-franciszek/art,20,papiez-do-duchownych-nie-kierujcie-sie-jedynie-skutecznoscia.html (dostęp: 5.06.2017).

Franciszek, Przemówienie na audiencji ogólnej, 5.06.2013, http://w2.vatican. va/content/francesco/pl/audiences/2013/documents/papa-francesco_20130605_ udienza-generale.html (27.11.2017).

Franciszek, Przemówienie z okazji odebrania nagrody Karola Wielkiego, Watykan 6.05.2016, http://w2.vatican.va/content/francesco/pl/speeches/2016/may/documents/papa-francesco_20160506_premio-carlo-magno.html (27.11.2017).

Główny Urząd Statystyczny, Informacja o rozmiarach $i$ kierunkach czasowej emigracji z Polski w latach 2004-2015, Warszawa 5.09.2016, http://stat.gov.pl/obszary-tematyczne/ ludnosc/migracje-zagraniczne-ludnosci/informacja-o-rozmiarach-i-kierunkach-emigracji-z-polski-w-latach-20042015,2,9.html (10.06.2017).

Gocko J., Aspekty etyczne wyjazdów zarobkowych, w: Wyjazdy zarobkowe. Szansa czy zagrożenie? Perspektywa społeczno-moralna, red. K. Glombik, P. Morciniec, Opole 2005, s. $183-195$.

Hułas M., Dylematy emigracji poakcesyjnej, „Cywilizacja” 32 (2010), s. 99-113.

Jan Paweł II, Być i czućsię Polakiem. Przemówienie do Polonii z całego świata, Rzym 1990, „Wspólnota Polska” 3 (2015), s. 3.

Jan Paweł II, Jesteście żywą częścią Polski. Spotkanie z Polonią w Wielkiej Brytanii, 30.05.1982, https://marszpolonia.com/2012/09/01/jan-pawel-ii-jestescie-zywa-czescia-polski/ (20.07.2017).

Jan Paweł II, Przemówienie do Polonii hiszpańskiej, Madryt, 2.11.1982, za: „Wspólnota Polska” 3 (2015), s. 13.

Jawna M., Emigracja zarobkowa a problem eurosieroctwa, „Ogrody Nauk i Sztuk” 3 (2013), s. 88-95.

Jerzak N., Rola i zadania Kościoła wobec emigrantów. Odpowiedzialność za obchodzenie się z emigrantami w Kościele, „Perspectiva. Legnickie Studia Teologiczno-Historyczne” 12 (2013), nr 2 (23), s. 61-74.

Kaczmarczyk P., Kępińska E., Napierała J., Próba oceny „natężenia” migracji w regionach wysyłajacych przez pryzmat gospodarstw domowych, w: Wspótczesne migracje zagraniczne Polaków. Aspekty lokalne i regionalne, red. W. P. Kaczmarczyk, Warszawa 2008, s. 113-131.

Kaczmarczyk P., Tyrowicz J., Współczesne migracje Polaków, „Bezrobocie org.pl” 1 (2007) nr 1, s. 1-15.

Kawczyńska-Butrym Z., Migracje. Wybrane zagadnienia, Lublin 2009. 
Kawczyńska-Butrym Z., Zdrowotne aspekty migracji, „Etos” 22 (2009) nr 3-4 (8788), s. 262-274.

Kluz M., Człowiek w konfrontacji ze współczesna migracją zarobkowa, „Studia Sandomierskie" 20 (2013) nr 2, s. 125-133.

Kozak S. Patologia eurosieroctwa $w$ Polsce. Skutki migracji zarobkowej dla dzieci i ich rodzin, Warszawa 2010.

Krotofil J., Rola religii w procesie przystosowania polskich migrantów do życia w Wielkiej Brytanii, w: Drogi i rozdroża, Migracje Polaków w Unii Europejskiej po 1 maja 2004 roku. Analiza psychologiczno-socjologiczna, red. H. Grzymała-Moszczyńska, A. Kwiatkowska, J. Roszak, Kraków 2010, s. 255-268.

Lachowicz W., Jezus Chrystus największym emigrantem i pielgrzymem, „Wspólnota Polska" 3 (2015), s. 44.

List Episkopatu Polski o duszpasterstwie emigracji, Warszawa 18-19.10.2006. http:// www.opoka.org.pl/biblioteka/W/WE/kep/duszp_emigracji_18102006.html(20.07.2017).

Młyński J., Szewczyk W., Migracje zarobkowe Polaków. Badania i refleksje, Tarnów 2010. Mostwin D., Emigranci polscy w USA, Lublin 1991.

Mój M., Migracje zarobkowe i ich konsekwencje dla rodzin na przykładzie województwa opolskiego, „Pogranicze. Polish Borderlands Studies” 3 (2015) nr 2, s. 175-190.

Niedźwiedzka D., Migracje i tożsamość. Od teorii do analizy przypadku, Kraków 2010.

Orczykowski A., Kościół wobec polskiej emigracji dawnej i współczesnej, „Cywilizacja” 32 (2010), s. 195-204.

Orzeszyna J., Pozytywny i negatywny aspekt migracji zarobkowej, ,Analecta Cracoviensia” 41 (2009), s. 261-280.

Pieronek T., Stolica Apostolska wobec migracji i migrantów, w: Migracje. Religie i Kościoły wobec migracji i migrantów, red. J. E. Zamojski, Warszawa 2009, s. 19-37.

Polak R., O emigracji uwagi krytyczne, „Cywilizacja” 32 (2010), s. 115-126.

Polska Misja Katolicka w Niemczech, https://www.pmk-niemcy.eu/polskiemisje.html (20.07.2017).

Skorowski H., Niebezpieczeństwo marginalizacji emigrantów i uchodźców w kontekście integracji Europejskiej, „Cywilizacja” 32 (2010), s. 31-40.

Walczak B., Dziecko, rodzina i szkoła wobec migracji rodzicielskich: 10 lat po akcesji do Unii Europejskiej, Warszawa 2014.

Więckiewicz B., Emigracja zarobkowa ijej konsekwencje w życiu rodzinnym, „Społeczeństwo i Rodzina" 4 (2008) nr 17, s. 101-108.

Wyżlic M., Communio małżeńskie w perspektywie migracji, „Roczniki Teologiczne” 54 (2007) z. 10, s. 153-168.

Wyżlic M., Migracja zarobkowa - zagrożeniem dla więzi małżeńskiej, „Cywilizacja” 32 (2010), s. 128-137.

Zwoliński A., Troska o naród na emigracji, „Cywilizacja” 32 (2010), s. 19-29. 